\title{
The antiproliferative potential of isolated emodin and aloe-emodin from Rheum ribes on different cancer cell lines
}

\author{
Mehmet Kadir ERDOĞAN *1, Can Ali AĞCA ${ }^{2}$, İbrahim Halil GEÇİBESLER ${ }^{3}$ \\ ORCID: 0000-0002-1579-5737; 0000-0002-0244-3767; 0000-0002-4473-2671
}

\author{
${ }^{1}$ Bingol University, Faculty of Arts and Science, Department of Biology, 12000, Bingöl, Turkey \\ ${ }^{2}$ Bingol University, Faculty of Arts and Science, Department of Molecular Biology and Genetics, Bingöl, Turkey \\ ${ }^{3}$ Bingol University, Faculty of Health Science, Department of Occupational Health and Safety, Laboratory of Natural \\ Product Research, 12000, Bingöl, Turkey
}

\begin{abstract}
Herbal compounds are important resources that used in the treatment of many diseases, and are inspiring in drug design and development. Rheum ribes, a perennial native plant, has potentially diverse medicinal effects, including antioxidant, antibacterial and anti-tumor activity. The key molecules associated with anticancer activity of $R$. ribes in tumor formation still remains unclear. The present study was aimed to elucidate the antiproliferative effects of two purified compounds, emodin and aloe-emodin, from $R$. ribes. In our study, chromatographic separation was used to purification of compounds. Experimental 1D and 2D 1H and 13C-NMR spectra helped us to confirm the chemical structures of emodin and aloe-emodin. The viability of human glioblastoma cell line (U373), human breast carcinoma cells (MCF-7), and human colorectal cancer cell line (HT-29) were detected by WST-1 proliferation assay as dose- and time-dependent. The isolated emodin and aloe-emodin from $R$. ribes, reduced viability of human glioblastoma, breast and colorectal cancer cell lines in dose- and time-dependent manner significantly. These antiproliferative effects may contribute as a possible strategy to the development of new therapeutic approaches in the treatment of cancer.
\end{abstract}

Key words: Rheum ribes, emodin, aloe-emodin, cancer, glioblastoma

\section{Rheum ribes'ten izole edilen emodin ve aloe-emodinin farklı kanser hücre hatları üzerindeki antiproliferatif potansiyeli}

\section{Özet}

Bitkisel bileşikler birçok hastalığın tedavisinde kullanılan ve ilaç tasarımı ve geliştirilmesinde ilham verici olan önemli kaynaklardır. Çok yıllık doğal bir bitki olan Rheum ribes, antioksidan, antibakteriyel ve anti-tümör aktivite dahil olmak üzere çeşitli potansiyel tıbbi etkilere sahiptir. $R$. ribes'in tümör oluşumundaki antikanser aktivitesi ile ilişkili anahtar moleküller hala belirsizliğini korumaktadır. Bu çalışmanın amacı, R. ribes'den saflaştırılan iki bileşik olan emodin ve aloe-emodinin antiproliferatif etkilerini aydınlatmaktır. Çalışmamızda bileşiklerin saflaştırılması için kromatografik ayırma kullanılmıştır. Deneysel 1D ve 2D 1H ve 13C-NMR spektrumları, emodin ve aloe-emodinin kimyasal yapılarını doğrulamamıza yardımcı oldu. İnsan glioblastom hücre hattının (U373), insan meme karsinom hücrelerinin (MCF-7) ve insan kolorektal kanser hücre hattının (HT-29) canlılığı, WST-1 proliferasyon analizi ile doza ve zamana bağlı olarak belirlendi. $R$. ribes'den izole edilmiş emodin ve aloe-emodin, insan glioblastomu, meme ve kolorektal kanser hücre hatlarının canlılı̆̆ını doza ve zamana bağlı bir şekilde önemli ölçüde azaltmıştır. Bu antiproliferatif etkinlik, kanser tedavisinde yeni terapötik yaklaşımların geliştirilmesine olası bir strateji olarak katkıda bulunabilir.

Anahtar kelimeler: Rheum ribes, emodin, aloe-emodin, kanser, glioblastoma

\footnotetext{
${ }^{*}$ Corresponding author / Haberleşmeden sorumlu yazar: Tel.: +904262160031; Fax.: +904262160031; E-mail: mkerdogan@ bingol.edu.tr

(C) Copyright 2020 by Biological Diversity and Conservation $\quad$ Received: 15.06.2020; $\quad$ Published: 15.08.2020 BioDiCon. 906-0420
} 


\section{Introduction}

Plants have been used for many centuries as nutrient, dietary supplementation, food additives, flavoring, and main source of drugs used in treatment of human sickness. In particular, the therapeutic properties of plants are currently being studied intensively for the development and discovery of newer therapeutics. Increasing incidence and high mortality rates have make highlighted the studies on the treatment of cancer in recent years. In cancer studies, phyto-compounds, which are compounds derived from plants, have an important position, because of their low or no cytotoxicity and clinical efficacy. Plant-derived compounds such as irinotecan, camptothecin, paclitaxel, vinblastine, combrestatin and etoposide, are used in clinical as chemotherapy drugs [1], and natural plant polyphenols, curcumin, quercetin, resveratrol, luteoline, gallic acid, hesperidine and genistein, etc., are also considered as promising adjuvants for cancer prevention and treatment [2].

Rheum species are known to have medical importance in the treatment of many diseases and disorders. Rheum ribes L., a member of the Polygonaceae family, is an important source in folk medicine. The medically important Rheum species are rich in anthracene-derived compounds [3]. R. ribes are used to treat laxative and joint disorders in Iran $[4,5]$. The Polygonaceae family also includes eight genera and seventy species in the Turkey. $R$. ribes is the only species in the family represented by the Turkey [6]. This plant grows naturally Turkey, Lebanon and Iran and it famous with names "Işgı̀n, Kurdish Banana and Uçgun".

R. ribes' young twigs and stems consumed as the salad, fresh vegetable and appetizing by the local people especially in Turkey's eastern and south-eastern Anatolia region. Besides, roots, leaves, flowers and stems are also used by natives in this area to treat the bile ducts, stomach discomforts, diarrhea, hemorrhoids, measles and smallpox as well its use as an appetite enhancer [7, 8]. Further, ethnobotanists in Jordan reported that the root of $R$. ribes was used by the public in diabetes, hypertension, obesity, kidney stone and sand [9]. Water decoction from the $R$. ribes roots was shown to reduce blood sugar in mice when given to mice diabetic with alloxan, but not hypoglycemia when administered to healthy mice forming the control group [10]. It was shown that isolates of the roots, leaves and stems of $R$. ribes had anti-viral and anti-microbial effect activity [11-14].

Phytochemical studies performed by the researchers on $R$. ribes species where collected from different provinces, such as Hakkari and Erzincan in Turkey. It has revealed the existence of different types of secondary metabolites chrysophanol, rhein, emodin, aloe-emodin, aloe-emodin-8-O-glucoside, physcion, physcion-8-O-glucoside, sennoside A, rhaponticin quercetin, 5-desoxyquercetin, quercetin 3-O-rhamnoside, quercetin 3-O-galactoside and quercetin 3-O-rutinoside [15-17].

The objective of this study was to purify the bioactive compounds, emodin (E) and aloe-emodin (AE), from $R$. ribes, and to determine the anti-proliferative activities of these purified compounds first time. The anti-proliferative activities of $\mathrm{E}$ and $\mathrm{AE}$ was observed in the cancer cell models of human glioblastoma, breast and colorectal cancer, U373, MCF-7 and HT-29 cell lines, respectively. This study elucidates the anticancer potential of $R$. ribes E and AE phytochemicals as potential anti-tumor agents.

\section{Materials and methods}

\subsection{Plant material}

$R$. ribes species, which were grown at $2000 \mathrm{~m}$ and higher in the natural habitats of Yelesen village of Bingöl, Turkey, were collected from the field following the flowering period during April-May months. The collection of the species was devoted to collecting without destroying nature. The species identification of the plant material was made by Alpaslan Koçak and the herbarium specimen was stored with KOÇAK 4003 registration number. R. ribes, collected in a suitable form from the field, was spread on unprinted paper and dried in a damp and shaded environment. The dried material was milled in the laboratory type mill so as not to exceed $3 \mathrm{~cm}$.

\subsection{Chemicals and reagents}

Dulbecco's modified eagle medium-high glucose (DMEM-HG), fetal bovine serum (FBS), penicillin/streptomycin and phosphate buffered saline (PBS) was obtained from Lonza (Walkersville, MD, USA). Tripan blue, tris HCl, tripsin-EDTA, dimethyl sulphoxide (DMSO), ethanol and methanol was obtained from SigmaAldrich (St. Louis, MO, USA). Hydrogen peroxide $\left(\mathrm{H}_{2} \mathrm{O}_{2}\right)$, sodium hydroxide $(\mathrm{NaOH})$ and glycine was purchased from Merck (Darmstadt, Germany). WST-1 [Water Soluble Tetrazolium-1; 2-(4-Iodophenyl)-3-(4-nitrophenyl)-5-(2, 4disulfophenyl)-2H-tetrazolium, monosodium salt)] cell proliferation assay kit was obtained from Intron Biotechnology (Gyeonggi-do, Korea).

\subsection{Extraction, fractination and isolation process}

Dried and ground plant material $(5 \mathrm{~kg})$ was taken in a glass flask and $10.0 \mathrm{~L}$ of methanol: chloroform $(1: 1 ; \mathrm{v} / \mathrm{v}$ ratio) was added and left to extraction for 2 days at the laboratory temperature. At the end of the second day, the extract 
was filtered with the help of the Whatman no 4 filter paper and the remaining pulp was allowed to be extracted again with the same amount and ratio of solvent system. This procedure was repeated three more times. The extracts obtained by the extraction process were combined and the solvents they contained were removed under reduced pressure at a temperature of $35^{\circ} \mathrm{C}$ by means of the rotary evaporator. Removal of the solvent system from the extracts yielded 523.8 $\mathrm{g}$ of dry extract with a yield of $10.476 \%$. The extraction yield was calculated by the following formula; \% Extract yield $=[$ Dry extract amount $(\mathrm{g}) /$ dry plant quantity $(\mathrm{g})] \mathrm{x} 100$. The dry extract was stored at $+4^{\circ} \mathrm{C}$ by taking an amber flask for anticancer activity and isolation studies. For isolation, $50 \mathrm{~g}$ of methanol: chloroform dry extract was dissolved in $1 \mathrm{~L}$ of distilled water. The aqueous extract was fractionated with chloroform $(8 \mathrm{x} 0.6 \mathrm{~L})$. At the end of the fractionation, $15.63 \mathrm{~g}$ of dry chloroform extract was obtained as a result of the removal of chloroforms by rotary evaporator. Isolation process was continued with this part. For the flash chromatography system, the pharmaceutical glass column $(5 \times 60 \mathrm{~cm})$ containing sephadex LH-20 column filler. The methanol: chloroform (35:65; v: v) solvent system was used as mobile phase and operating conditions for elution collection were adjusted to $2 \mathrm{~mL}$ per minute. A total of 126 sub-fractions were eluted in each elution volume of $10 \mathrm{~mL}$. As a result of the chromatographic separation, the emodine $(68 \mathrm{mg})$ and aloe-emodin (56 mg) were obtained in the sub-fraction 37 and 75, respectively (Figure 1).<smiles>[R]C1=C[C@H]2C(=O)c3ccc([R])cc3C(=O)[C@@H]2C(O)=C1</smiles>

$\begin{array}{cll} & \mathrm{R}_{1} & \mathrm{R}_{2} \\ \text { Emodin } & -\mathrm{OH} & -\mathrm{CH}_{3} \\ \text { Aloe-emodin } & -\mathrm{H} & -\mathrm{CH}_{2} \mathrm{OH}\end{array}$

Figure 1. Chemical structures of emodin and aloe-emodin from R.ribes

\subsection{Cell lines and cell culture conditions}

Human glioblastoma cells (U373), breast cancer cell line (MCF-7) and colorectal adenocarcinoma cells (HT29), were obtained from the Central Laboratory Research and Application Center of Bingol University, Turkey. All cell lines were cultured in Dulbecco's Modified Eagle's Medium (DMEM) supplemented with 10\% fetal bovine serum (FBS) and $1 \%$ penicillin/streptomycin, and cells were maintained in a humidified atmosphere of $5 \% \mathrm{CO}_{2}$ at $37^{\circ} \mathrm{C}[18]$.

\subsection{Cell viability}

The dose- and time-dependent antiproliferative effects of $\mathrm{E}$ and $\mathrm{AE}$ from $R$. ribes, was measured using the WST-1 cell proliferation assay kit according to manufacturer`s protocol (Intron Biotechnology, Gyeonggi-do, Korea), in vitro. Cells $\left(5 \times 10^{3}\right.$ cells/well) were seeded into 96 -well culture plates and incubated at $37^{\circ} \mathrm{C}$ and $5 \% \mathrm{CO}_{2}$ overnight. The plates were treated with various concentrations $(1,10,25,50$, and $100 \mu \mathrm{g} / \mathrm{mL})$ of E and AE for 24 and 48 hours. The control groups were exposed to $0.05 \%$ DMSO containing media. Culture medium was replaced by fresh medium and $10 \mu \mathrm{l}$ of WST-1 reagent were pipetted into wells. After $3 \mathrm{~h}$ incubation period, the amount of soluble formazan dye produced by metabolically active cells was measured with an ELISA microplate reader (SpectraMax 384 Plus, Molecular Devices, USA) at $450 \mathrm{~nm}$ as absorbance (optical density (OD). The mixture of WST-1 reagent and culture medium without cells was evaluated as a background control. To determine percentage of cell survival that formula was used: $\%$ cell survival $=$ ODtest $/$ ODcontrol $\times 100 \%$. The half maximal inhibitory concentration $\left(\mathrm{IC}_{50}\right)$ value for each test group was calculated according to the findings.

\subsection{Statistical analysis}

Each assay was performed in three experiments and mean \pm standard deviation (SD) values were calculated. Statistical analysis of the findings were evaluated by t-test and one-way ANOVA test using GraphPad Prism 8.0 (GraphPad Software, San Diego, CA, USA). $P$ values $<0.05$ was assumed to be statistically significant.

\section{Results}

\subsection{Chemical characterization}

The ${ }^{1} \mathrm{H}$ and ${ }^{13} \mathrm{C}$ NMR spectra of $\mathrm{E}$ and $\mathrm{AE}$ compounds were analyzed using $600 \mathrm{MHz} \mathrm{NMR}$ spectrometer (Bruker AVANCE). $7 \mathrm{mg}$ of each compound was taken to NMR tube and dissolved in $450 \mu \mathrm{L}$ of DMSO-d6. The chemical shifts of compounds that consistent with the literature was documented in the table 1 [19, 20]. Also chemical structures of emodin and aloe-emodin confirmed by experimental $1 \mathrm{D}$ and $2 \mathrm{D}{ }^{1} \mathrm{H}$ and ${ }^{13} \mathrm{C}-\mathrm{NMR}$ spectra. 
Table 1 . The ${ }^{3} \mathrm{C}-\mathrm{NMR}$ chemical shifts $(\delta ; \mathrm{ppm})$ of the emodin, aloe-emodin and they comparison with literature data $\left(150 \mathrm{MHz}, \mathrm{DMSO}-d_{6}\right)$

\begin{tabular}{lllll}
\hline & $\begin{array}{l}\text { Emodin } \\
\text { (Experimental) }\end{array}$ & $\begin{array}{l}\text { Emodin } \\
{[\mathbf{1 9}]}\end{array}$ & $\begin{array}{l}\text { Aloe-emodin } \\
\text { (Experimental) }\end{array}$ & $\begin{array}{l}\text { Aloe-emodin } \\
{[\mathbf{2 0}]}\end{array}$ \\
\hline $\mathbf{C 1}$ & 166.03 & 166.44 & 161.76 & 161.8 \\
$\mathbf{C 2}$ & 108.39 & 108.17 & 117.51 & 117.7 \\
$\mathbf{C 3}$ & 161.87 & 162.14 & 154.14 & 154.5 \\
$\mathbf{C 4}$ & 109.43 & 109.36 & 124.78 & 125.1 \\
$\mathbf{C 5}$ & 124.59 & 124.51 & 121.06 & 121.4 \\
$\mathbf{C 6}$ & 148.71 & 148.76 & 137.72 & 138.0 \\
$\mathbf{C 7}$ & 120.93 & 121.23 & 119.74 & 120.0 \\
$\mathbf{C 8}$ & 164.90 & 166.17 & 162.06 & 162.1 \\
$\mathbf{C 9}$ & 190.19 & 190.43 & 191.97 & 191.9 \\
$\mathbf{C 1 0}$ & 181.85 & 181.34 & 181.70 & 182.1 \\
$\mathbf{C 4 a}$ & 135.58 & 135.47 & 133.64 & 134.7 \\
$\mathbf{C 8 a}$ & 113.85 & 113.90 & 114.73 & 114.9 \\
$\mathbf{C 9 a}$ & 109.22 & 109.36 & 116.18 & 116.4 \\
$\mathbf{C 1 0 a}$ & 133.29 & 133.10 & 133.41 & 133.5 \\
$\mathbf{- O C H}$ & 21.96 & 21.50 & & 63.3 \\
$\mathbf{- C H 3}$ & & & 62.50 & \\
\hline
\end{tabular}

\subsection{Antiproliferative effects of emodin and aloe-emodin from $R$. ribes}

The dose- and time-dependent antiproliferative activities of E and AE were assesed in U373, MCF-7 and HT-29 cells. The increasing concentrations of $\mathrm{E}$ and AE were treated cell lines. After 24 and $48 \mathrm{~h}$ treatment, the viability of the cells were observed with WST-1 cell proliferation assay. The GraphPad Prism 8 software was used to estimate the halfmaximal inhibitory concentrations $\left(\mathrm{IC}_{50}\right)$.

A

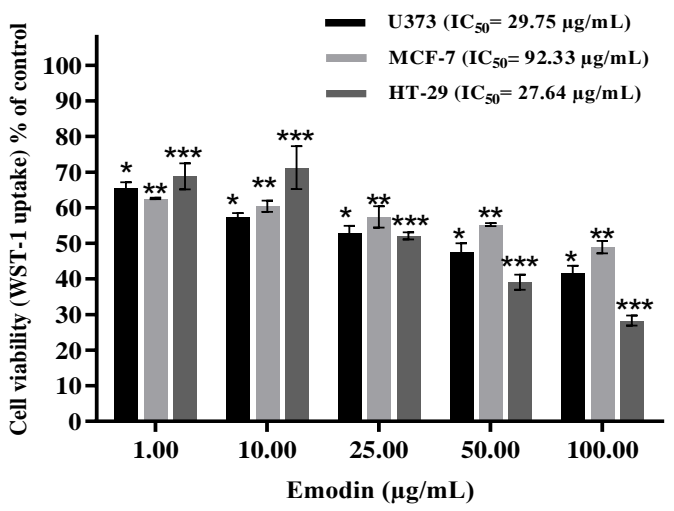

C

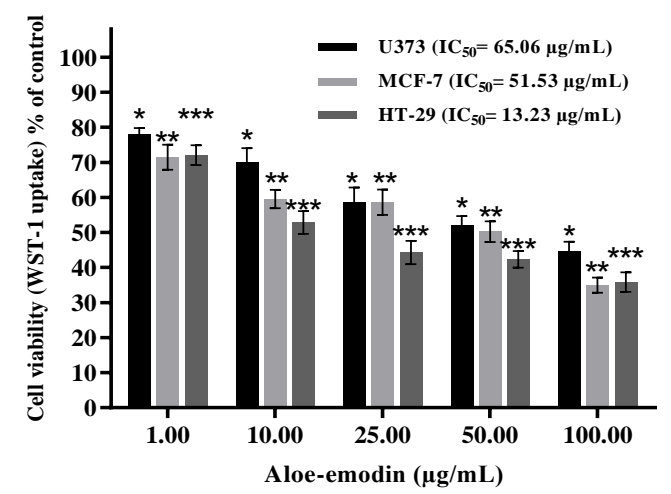

B

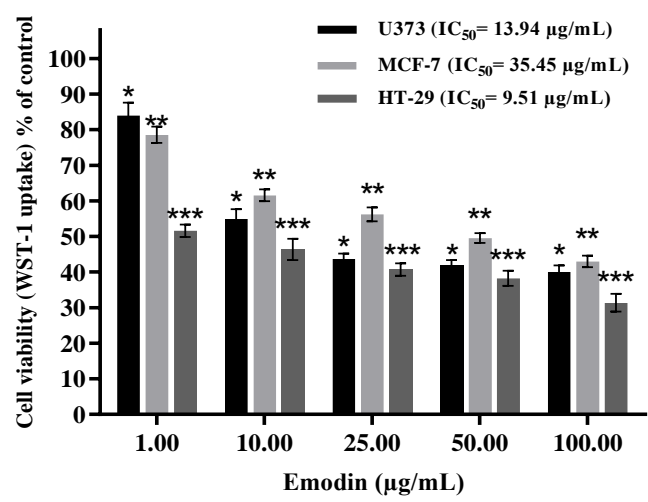

D

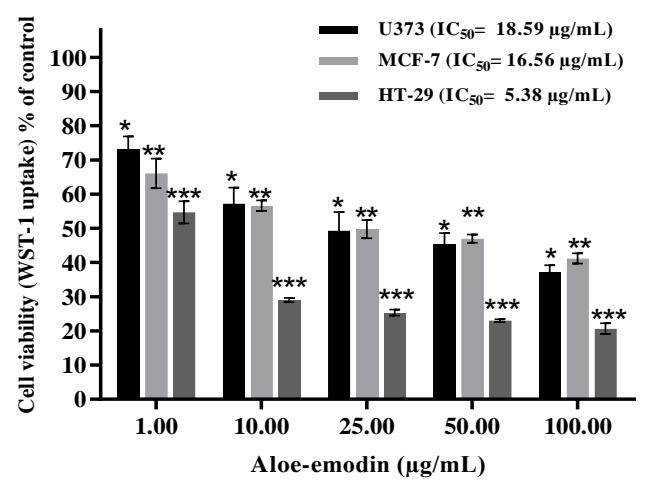

Figure 2. Emodin and aloe-emodin, from $R$. ribes, decreases the viability of cancer cells in vitro. U373, MCF-7 and HT29 cells, grown in conditions which as described in materials and methods. (A) The cancer cells were treated for $24 \mathrm{~h}$ with different concentrations of E. (B) U373, MCF-7 and HT-29 cells were treated for $48 \mathrm{~h}$ with various concentrations of E. (C) The cells were treated with different AE concentrations for $24 \mathrm{~h}$. (D) U373, MCF-7 and HT-29 cells were treated with various concentrations of AE for $48 \mathrm{~h}$. The GraphPad Prism 8 programme was used to calculate the $\mathrm{IC}_{50}$ values for $\mathrm{E}$ and $\mathrm{AE}$. Asterisks indicate statistical significance by comparison of treatment groups with control cells $(100 \%$, cells treated with $0.05 \%$ DMSO containing media). The results are mean \pm SD of three experiments (U373 $* \mathrm{p}<0.001$; MCF$7 * * \mathrm{p}<0.001$ and HT $-29 * * * \mathrm{p}<0.001$, when compared to control). 
E and AE exhibited dose- and time-dependent effects on viability of all cell lines. As shown in Fig 2, the decreases in percentage of viability were statistically significant in all treatment groups compared to control (U373 $* \mathrm{p}<0.001$; MCF-7 $* * \mathrm{p}<0.001$; and HT-29***p<0.001). Treatment with E at $1 \mu \mathrm{g} / \mathrm{mL}$ significantly reduced viability in all three cell lines in $24 \mathrm{~h}$ treatments, however, the decrease in viability of U373 and MCF-7 cells was milder at 48 hours treatment of the same concentration. The $\mathrm{IC}_{50}$ values of $\mathrm{E}$, at $24 \mathrm{~h}$ treatment, were $29.75,92.33 \mathrm{and} 27.64 \mu \mathrm{g} / \mathrm{mL}$ for U373, MCF-7 and HT-29 cell lines, respectively (Fig 2A). The required concentrations of E to inhibite the growth of $50 \%$ of cells $\left(\mathrm{IC}_{50}\right)$ for U373, MCF-7 and HT-29 were 13.94, 35.45 and $9.51 \mu \mathrm{g} / \mathrm{mL}$ at 48 hours (Fig 2B). These results indicate that, $48 \mathrm{~h}$ treatment with $\mathrm{E}$ reduces $\mathrm{IC}_{50}$ values by more than half, compared to $24 \mathrm{~h}$ treatment. On the other hand, the viability of the cells decreased significantly in treated with AE at $1 \mu \mathrm{g} / \mathrm{mL}$, which was the lowest concentration, but at the highest concentration, $100 \mu \mathrm{g} / \mathrm{mL}$, the viability of all cells was the lowest at 48 hours of treatment. AE treatment at $100 \mu \mathrm{g} / \mathrm{mL}$ in $48 \mathrm{~h}$, reduced the viability of U373 human glioblastoma cells, MCF-7 breast cancer cell line and HT-29 colorectal adenocarcinoma cells to $37.1,41.2$ and $20.7 \%$, respectively (Fig $2 \mathrm{D})$. The IC 50 values of AE were 65.06, 51.53, $13.23 \mu \mathrm{g} / \mathrm{mL}$ and 18.59, 16.56, $5.38 \mu \mathrm{g} / \mathrm{mL}$ in U373, MCF-7 and HT-29 cell lines, at 24 and $48 \mathrm{~h}$ treatment, respectively (Fig 2C, Fig 2D). $\mathrm{IC}_{50}$ values in $48 \mathrm{~h} \mathrm{AE}$ treatment groups, also decreased approximately three-fold compared to $24 \mathrm{~h}$ treatments.

\section{Conclusions and discussion}

Cancer causes huge losses as a major health problem all over the world. Many new therapeutics and clinical treatments have been proposed to combat this disease. In this context, herbal-based treatment approaches stand out in the fight against cancer with their low toxic effects and efficacy. The therapeutic potential of medicinal plants has recently aroused a great interest in the treatment and prevention of many diseases, such as cancer [21]. The anticarcinogenic effect of Rheum genus have been shown in several studies. It was determined that $R$. officinale water extract was significantly growth inhibitory on A549 and MCF-7 cell lines and $\mathrm{IC}_{50}$ values were 620 and $515 \mu \mathrm{g} / \mathrm{mL}$ [22]. R. emodi water and methanol extracts have been reported to show anticancer activity against two human carcinomas (MDA-MB-435S breast cancer and Hep3B liver carcinoma cell lines) [23]. R. ribes ethanol, water and methanol extracts significantly reduce the viability of HCT-116, A2780, MCF-7 and PC-3 cells, especially at concentrations of 25,50 and $100 \mu \mathrm{g} / \mathrm{mL}$, and in the same cell lines the $\mathrm{IC}_{50}$ values were determined between 14.2-42.2 $\mu \mathrm{g} / \mathrm{mL}$ [24]. In another study, ethanolic extract of $R$. ribes was showed significantly cytotoxic activity against SW742 and MCF-7 cells, and this extract inhibited the half of the cells at concentrations of 46.4 and $51.3 \mu \mathrm{g} / \mathrm{mL}$, respectively [25]. R.ribes butanol fraction exhibited antiproliferative activity on MCF-7 human breast cancer cells, and IC 50 value was determined as $36 \mu \mathrm{g} / \mathrm{mL}$ [26]. R.ribes is particularly rich in anthraquinone compounds, and emodin and aloeemodin are among the main components [15-17]. In this study, the anti-proliferative effects of two anthraquinone derivatives, emodin (1,3,8 trihydroxy-6-methylanthraquinone) and aloe-emodin (1,8-dihydroxy-3-hydroxymethylanthraquinone), which isolated from R.ribes, were investigated on different cancer cell lines.

Glioblastoma is a malignant brain tumor that affects stem/progenitor cells in the brain and it has the rapidly spread potential in adults [27]. Ismail et al. demonstrated that aloe-emodin inhibits proliferation of U87 malignant glioma cells in a dose and time dependent manner and has an $\mathrm{IC}_{50}$ value of $58.6 \mu \mathrm{g} / \mathrm{mL}$ in $24 \mathrm{~h}$ treatment and 25.0 $\mu \mathrm{g} / \mathrm{mL}$ in $48 \mathrm{~h}$ treatment [28]. In accordance with this study, we found that aloe-emodin, that isolated from $R$. ribes, was decreased the viability of U373 glioblastoma cells in a dose and time dependent manner, and the $\mathrm{IC}_{50}$ value was 65.1 $\mu \mathrm{g} / \mathrm{mL}$ and $18.6 \mu \mathrm{g} / \mathrm{mL}$ at 24 and $48 \mathrm{~h}$ treatment, respectively. We have also demonstrated that isolated emodine significantly inhibits the viability of U373 glioblastoma cells depending on increasing time and concentration.

Breast cancer is the most common cancer among women and accounts for $9.6 \%$ of cancer-related deaths worldwide [29]. Kang et al. determined the $\mathrm{IC}_{50}$ value of the emodin and aloe-emodin isolated from R. palmatum for 48 $\mathrm{h}$ in MCF-7 breast cancer cells as 16.4 and $12.6 \mu \mathrm{g} / \mathrm{mL}$, respectively [30]. Similarly, we found the $\mathrm{IC}_{50}$ value as 16.6 $\mu \mathrm{g} / \mathrm{mL}$ for $R$. ribes' aloe-emodin in MCF-7 cells at $48 \mathrm{~h}$ treatment. However, isolated emodin from $R$. ribes was had a milder antiproliferative effect than aloe-emodin. It has been reported that, emodin and aloe-emodin significantly inhibited the proliferation of MCF-7 cells in a dose and time dependent manner and show anticancer activity [31]. We can also say that, emodin and aloe-emodin show anticancer activity depending on dose and concentration, and these two compounds make important contributions to R.ribes anticancer potential.

Colorectal cancer is the second cause of cancer-related deaths in both men and women [32]. Suboj et al. treated WiDr, RKO, SW 480 and SW 620 colon adenocarcinoma cells for $48 \mathrm{~h}$ with commercially AE, and showed that AE has a dose-dependent antiproliferative effect and it was arrested the cell cycle in the G2/M phase [33]. Similarly, in our study, AE exhibited dose-dependent inhibition in the proliferation of HT-29 colorectal cancer cells. In addition, both emodin and aloe-emodin, that isolated from R.ribes, significantly inhibited the proliferation of HT-29 colorectal adenocarcinoma cells, even at very low concentrations.

Overall, these results indicate that, isolated emodin and aloe-emodin from $R$. ribes have a significant antiproliferative effect in human breast, colon and glioma cancer cell lines, and therewithal suggesting that these isolated compounds from $R$. ribes have potential therapeutic efficacy in the prevention and treatment of cancer. However, further investigations are needed to clarify the molecular mechanisms of these isolated compounds. 


\section{Acknowledgements}

This study was supported by The Scientific Research Projects Coordination Unit of Bingol University (Project no: BAP-FEF.2017.00.010).

\section{References}

[1] Saklani, A., Kutty, S. K. (2008). Plant-derived compounds in clinical trials. Drug discovery today, 13(3-4), 161171. https://doi.org/10.1016/j.drudis.2007.10.010

[2] Zhou, Y., Zheng, J., Li, Y., Xu, D. P., Li, S., Chen, Y. M., Li, H. B. (2016). Natural polyphenols for prevention and treatment of cancer. Nutrients, 8(8), 515. https://doi.org/10.3390/nu8080515

[3] Kashiwada, Y., Nonaka, G. I., Nishioka, I., Yamagishi, T. (1988). Galloyl and hydroxycinnamoylglucoses from rhubarb. Phytochemistry, 27(5), 1473-1477. https://doi.org/10.1016/0031-9422(88)80218-8

[4] Öztürk, M., Aydoğmuş-Öztürk, F., Duru, M. E., Topçu, G. (2007). Antioxidant activity of stem and root extracts of Rhubarb (Rheum ribes): An edible medicinal plant. Food chemistry, 103(2), 623-630. https://doi.org/10.1016/j.foodchem.2006.09.005

[5] Shockravi, A., Agh Nasiri, K. (1997). Synthesis of 1, 2, 3, 4, 5, 6, 7, 8-Octahydro-9-Ethoxy-10-Hydroxy-1Anthracenone [OEHA]. Iranian Journal of Chemistry and Chemical Engineering (IJCCE), 16(1), 10-14.

[6] Cullen, J. (1966). Rheum L. In PH. Davis (Ed.). Flora of Turkey and the East Aegean Islands (Vol. 2, pp. 268269). Edinburgh: Edinburgh University Press.

[7] Baytop, T. (1999). Rheum ribes L. In T. Baytop (Ed.). Therapy with medicinal plants in turkey (Vol. 1, pp. 319320). Istanbul: Nobel T1p Publication Press.

[8] Tabata, M., Sezik, E., Honda, G., Yeşilada, E., Fukui, H., Goto, K., Ikeshiro, Y. (1994). Traditional medicine in Turkey III. Folk medicine in East Anatolia, Van and Bitlis provinces. Int. J of Pharmacognosy, 32(1), 3-12. https://doi.org/10.3109/13880209409082966

[9] Abu-Irmaileh, B. E., Afifi, F. U. (2003). Herbal medicine in Jordan with special emphasis on commonly used herbs. Journal of Ethnopharmacology, 89(2-3), 193-197. https://doi.org/10.1016/S0378-8741(03)00283-6

[10] Ozbek, H., Ceylan, E., Kara, M., Ozgokce, F., Koyuncu, M. (2004). Hypoglycemic effect of Rheum ribes roots in alloxan induced diabetic and normal mice. Scandinavian Journal of Laboratory Animal Science, 31(2), 113115 .

[11] Bazzaz, B.S.F., Khajehkaramadin, M., Shokooheizadeh, H.R. (2005). In vitro antibacterial activity of Rheum ribes extract obtained from various plant parts against clinical 1solates of gram-negative pathogens. Iran. J. Pharm. Res, 2, 87-91.

[12] Bonjar, G. S. (2004). Evaluation of antibacterial properties of Iranian medicinal-plants against Micrococcus luteus, Serratia marcescens, Klebsiella pneumoniae and Bordetella bronchoseptica. Asian J. Plant Sci, 3(1), 8286.

[13] Bonjar, G. S. (2004). Inhibition of three isolates of Staphylococcus aureus mediated by plants used by Iranian native people. $J$ Med Sci, 4(2), 136-141.

[14] Hudson, J. B., Lee, M. K., Sener, B., Erdemoglu, N. (2000). Antiviral activities in extracts of Turkish medicinal plants. Pharmaceutical biology, 38(3), 171-175. https://doi.org/10.1076/1388-0209(200007)3831-SFT171

[15] Mericli, A. H., Tuzlaci, E. (1990). Constituents of Rheum ribes. Fitoterapia, 61(4).

[16] Tuzlac1, E., Meriçli, A. H. (1991, May). Some studies on Isgın (Rheum ribes) and its distribution in Turkey. In Proceeding of the 9th Symposium on Plant Drugs (16-19 May 1991, Eskisehir), Turkey (pp. 336-341).

[17] Tosun, F., Kizilay, C. A. (2003). Anthraquinones and flavonoids from Rheum ribes. J Fac Pharm Ankara, 32, 31-5.

[18] Erdoğan, M. K., Ağca, C. A., Aşkıı, H. (2019). Enhanced antiproliferative and apoptotic effects of 5fluorouracil by combined with Pistacia eurycarpa Extracts on human colorectal cancer cells. Biological Diversity and Conservation, 12(1), 27-38. https://doi.org/10.5505/biodicon.2019.57441

[19] Barros, I. B. D., Daniel, J. F. D. S., Pinto, J. P., Rezende, M. I., Braz Filho, R., Ferreira, D. T. (2011). Phytochemical and antifungal activity of anthraquinones and root and leaf extracts of Coccoloba mollis on phytopathogens. Brazilian Archives of Biology and Technology, 54(3), 535-541. https://doi.org/10.1590/S151689132011000300015 
[20] Zhang, Y. Z., Lu, Y. H., Wei, D. Z., Chou, G. X., Zhu, E. Y. (2007). Preparative isolation and purification of hydroxyanthraquinones from Rheum tanguticum Maxim. on normal phase silica gel: using a Flash Master Personal system. Preparative biochemistry \& biotechnology, $37(3), \quad 185-193$. https://doi.org/10.1080/10826060701386661

[21] Erdoğan, M. K., Geçibesler, İ. H., Behçet, L. (2020). Chemical constituents, antioxidant, antiproliferative and apoptotic effects of a new endemic Boraginaceae species: Paracaryum bingoelianum. Results in Chemistry, 2 , 100032. https://doi.org/10.1016/j.rechem.2020.100032

[22] Li, W.Y., Chan, S.W., Guo, D.J., Chung, M.K., Leung, T.Y., Yu, P.H.F. (2009). Water extract of Rheum officinale Baill. induces apoptosis in human lung adenocarcinoma A549 and human breast cancer MCF-7 cell lines. J. Ethnopharmacol., 124(2), 251-256. https://doi.org/10.1016/j.jep.2009.04.030

[23] Rajkumar, V., Guha, G., Kumar, R. A. (2011). Antioxidant and anti-cancer potentials of Rheum emodi rhizome extracts. Evidence-based Complementary and Alternative Medicine, 2011, 1-9. https://doi.org/10.1093/ecam/neq048

[24] Keser, S., Keser, F., Karatepe, M., Kaygili, O., Tekin, S., Turkoglu, I., Demir, E., Yilmaz, O., Kirbag, S., Sandal, S. (2019). Bioactive contents, In vitro antiradical, antimicrobial and cytotoxic properties of rhubarb (Rheum ribes L.) extracts. Natural product research, 1-5. https://doi.org/10.1080/14786419.2018.1560294

[25] Sardari, S., Shokrgozar, M. A., Ghavami, G. (2009). Cheminformatics based selection and cytotoxic effects of herbal extracts. Toxicology in vitro, 23(7), 1412-1421. https://doi.org/10.1016/j.tiv.2009.07.011

[26] Achakzai, J. K., Anwar Panezai, M., Kakar, M. A., Kakar, A. M., Kakar, S., Khan, J., Tareen, A. K. (2019). In vitro anticancer MCF-7, anti-inflammatory, and brine shrimp lethality assay (BSLA) and GC-MS analysis of whole plant butanol fraction of Rheum ribes (WBFRR). BioMed research international, 2019. https://doi.org/10.1155/2019/3264846

[27] Mega, A., Hartmark Nilsen, M., Leiss, L. W., Tobin, N. P., Miletic, H., Sleire, L., Enger, P. Ø. (2020). Astrocytes enhance glioblastoma growth. Glia, 68(2), 316-327. https://doi.org/10.1002/glia.23718

[28] Ismail, S., Haris, K., Abdul Ghani, A. R. I., Abdullah, J. M., Johan, M. F., Mohamed Yusoff, A. A. (2013). Enhanced induction of cell cycle arrest and apoptosis via the mitochondrial membrane potential disruption in human U87 malignant glioma cells by aloe emodin. Journal of Asian natural products research, 15(9), 10031012. https://doi.org/10.1080/10286020.2013.818982

[29] Tang, Y., Fu, F., Gao, H., Shen, L., Chi, I., Bai, Z. (2019). Art therapy for anxiety, depression, and fatigue in females with breast cancer: A systematic review. Journal of psychosocial oncology, 37(1), 79-95. https://doi.org/10.1080/07347332.2018.1506855

[30] Kang, S. C., Lee, C. M., Choung, E. S., Bak, J. P., Bae, J. J., Yoo, H. S., Zee, O. P. (2008). Anti-proliferative effects of estrogen receptor-modulating compounds isolated from Rheum palmatum. Archives of Pharmacal Research, 31(6), 722-726. https://doi.org/10.1007/s12272-001-1218-1

[31] Huang, P. H., Huang, C. Y., Chen, M. C., Lee, Y. T., Yue, C. H., Wang, H. Y., Lin, H. (2013). Emodin and aloeemodin suppress breast cancer cell proliferation through ER $\alpha$ inhibition. Evidence-Based Complementary and Alternative Medicine, 2013. https://doi.org/10.1155/2013/376123

[32] Bray, F., Ferlay, J., Soerjomataram, I., Siegel, R. L., Torre, L. A., Jemal, A. (2018). Global cancer statistics 2018: GLOBOCAN estimates of incidence and mortality worldwide for 36 cancers in 185 countries. $C A$ : $a$ cancer journal for clinicians, 68(6), 394-424. https://doi.org/10.3322/caac.21492

[33] Suboj, P., Babykutty, S., Srinivas, P., Gopala, S. (2012). Aloe emodin induces G2 / M cell cycle arrest and apoptosis via activation of caspase-6 in human colon cancer cells. Pharmacology, 89 (1-2), 91-98. https://doi.org/10.1159/000335659 


\section{Supplementary data}

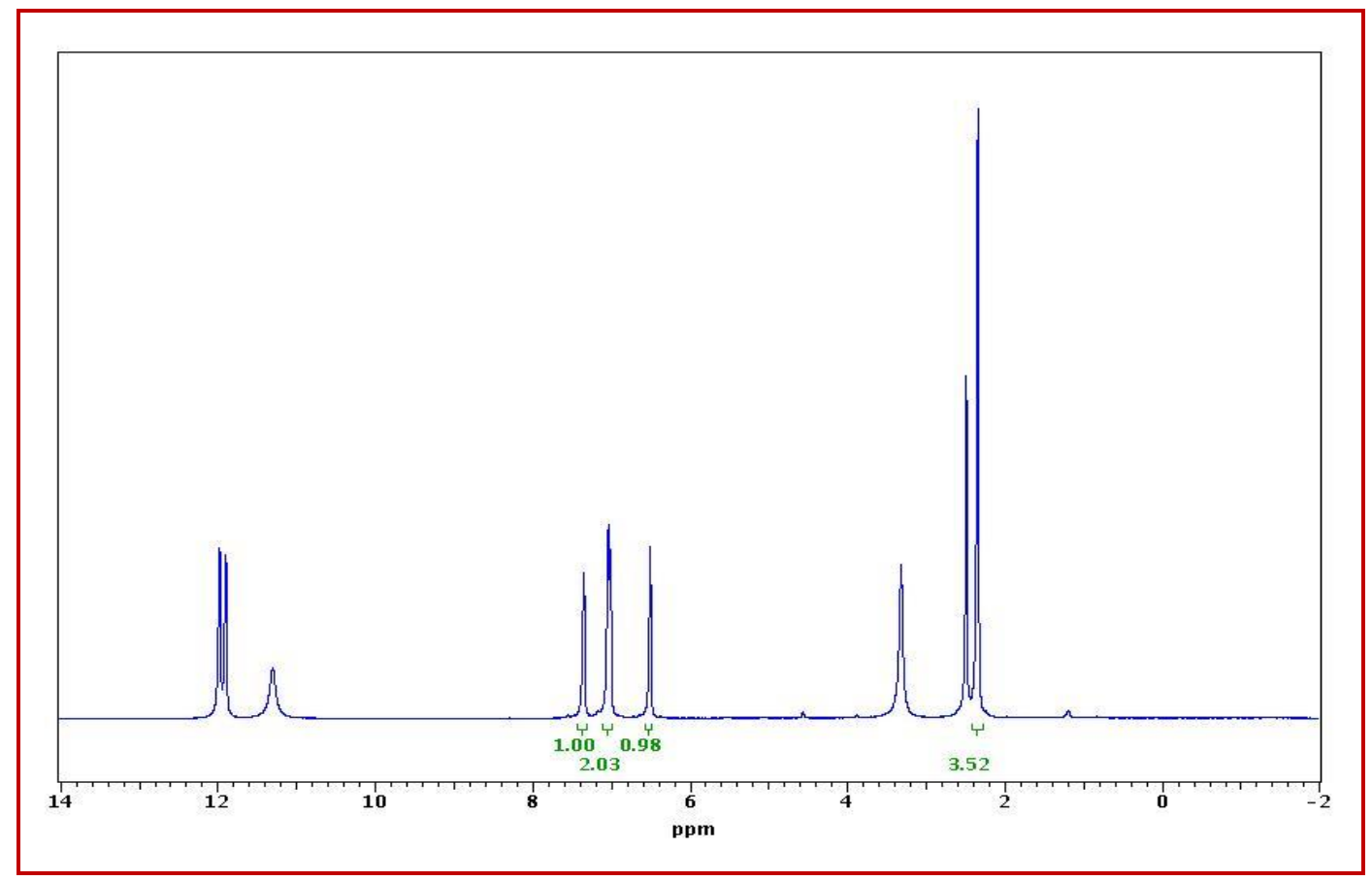

Figure S1. 1 H-NMR spectrum of the emodin compound (1 H-NMR: 600 MHz; DMSO-d 6)

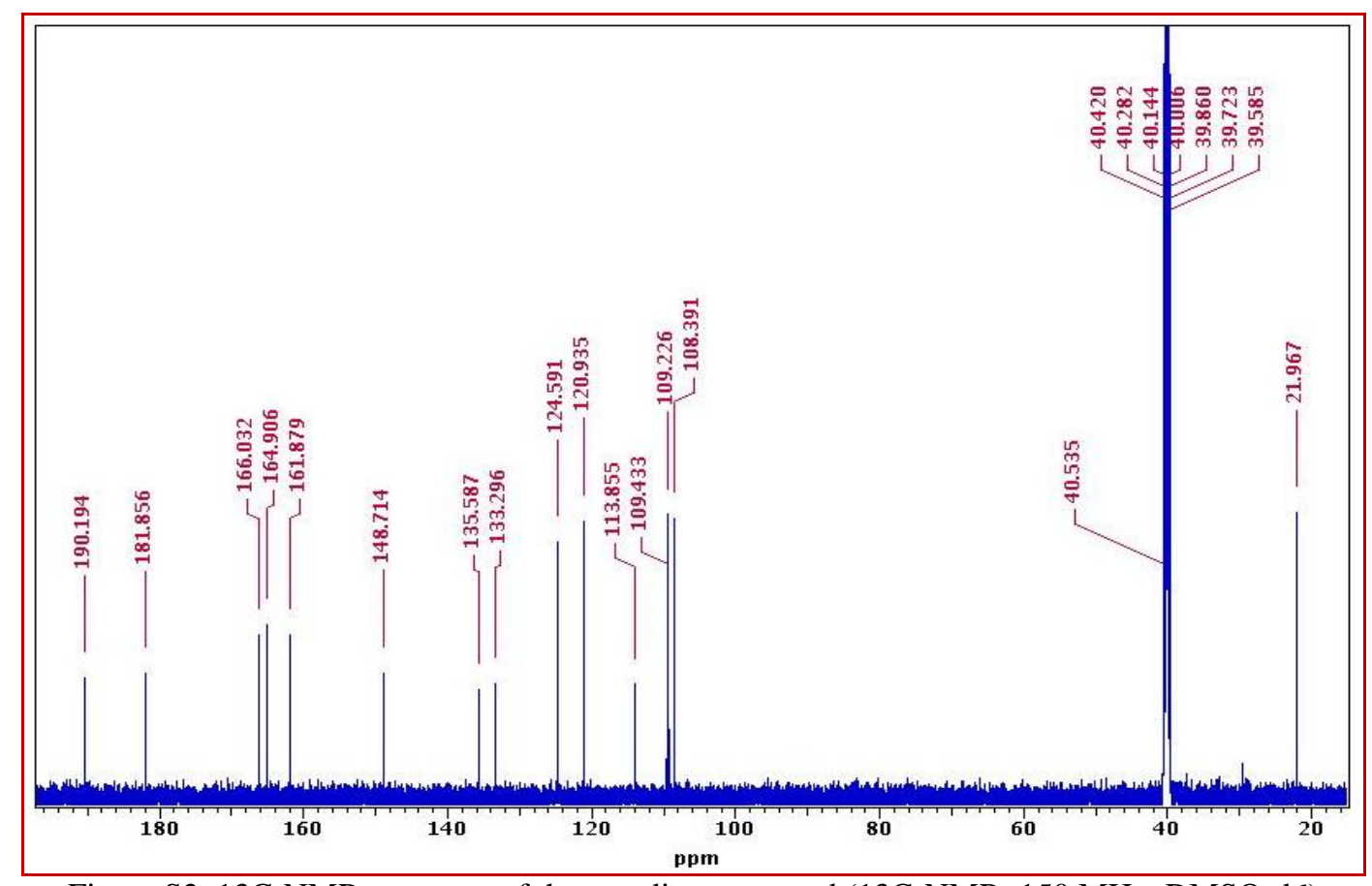

Figure S2. 13C-NMR spectrum of the emodin compound (13C-NMR: $150 \mathrm{MHz}$; DMSO-d6) 


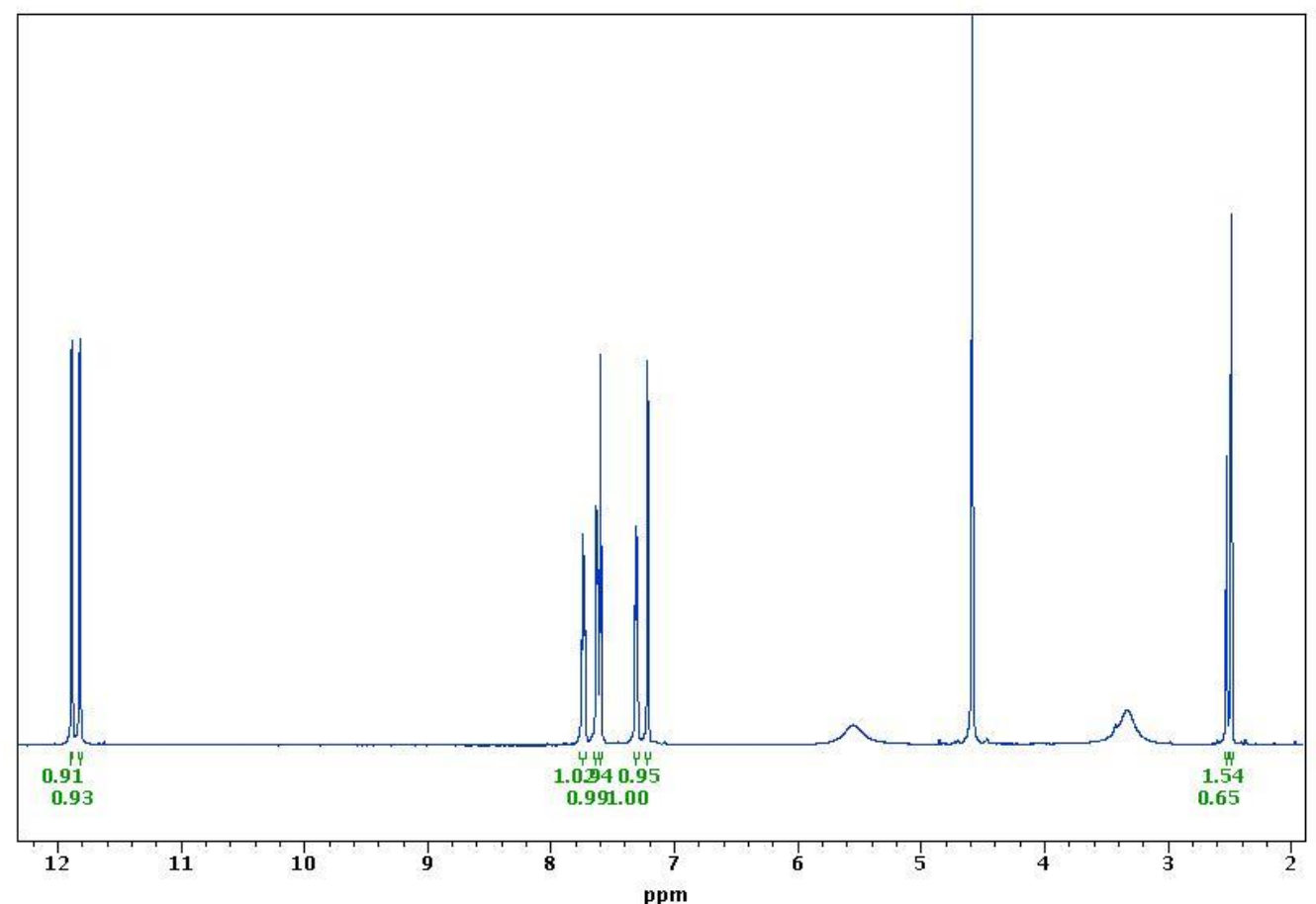

Figure S3. 1 H-NMR spectrum of the aloe-emodin compound (1 H-NMR: 600 MHz; DMSO-d 6).

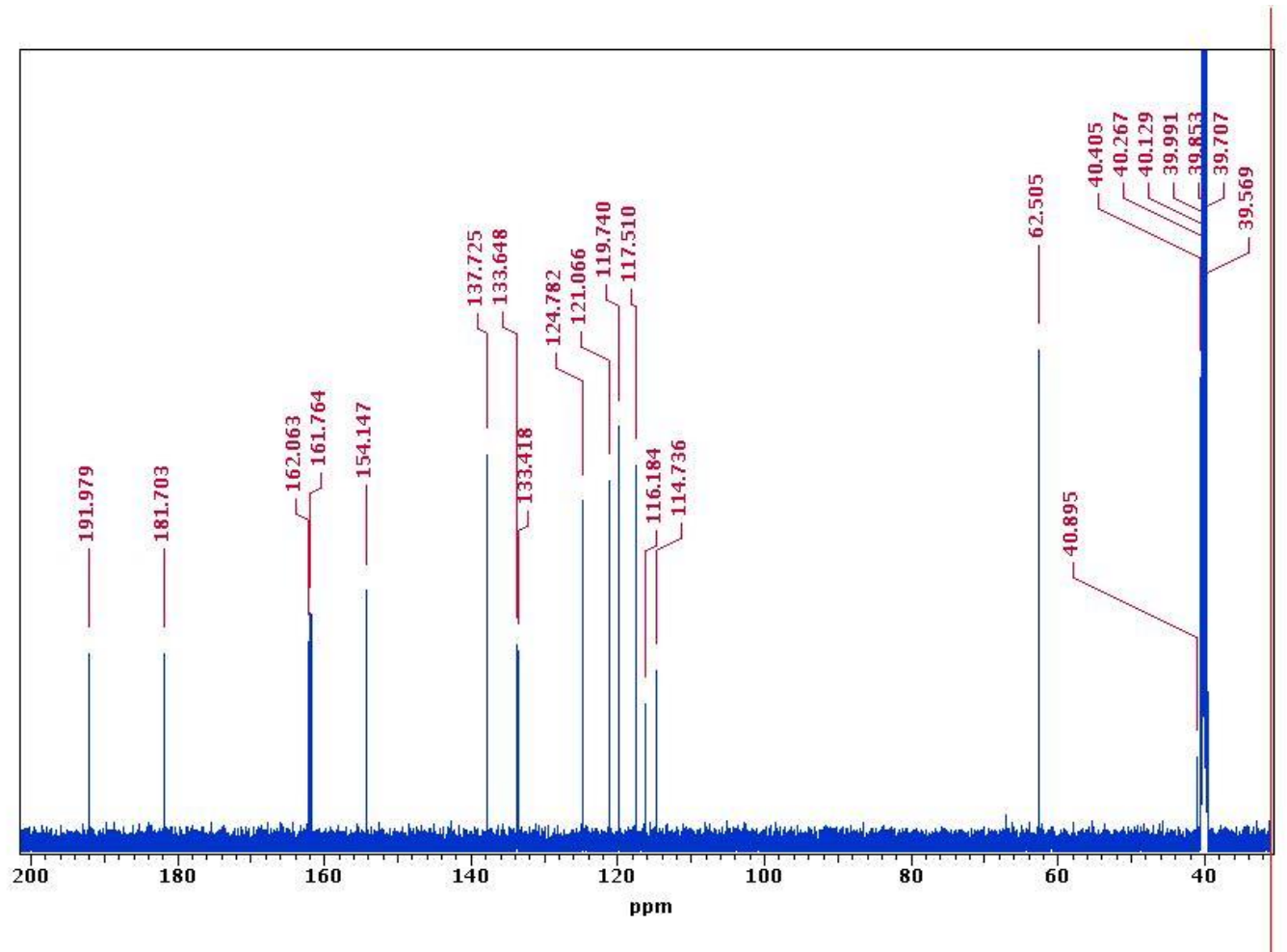

Figure S4. 13 C-NMR spectrum of aloe-emodin compound (13 C-NMR: $150 \mathrm{MHz}$; DMSO-d 6) 